\title{
Susceptibility of Clonal Seedlings of Eucalyptus spp. to Powdery Mildew Disease
}

\author{
Marciéli Pitorini Bovolini ${ }^{1}$, Marília Lazarotto ${ }^{1}$, Mateus Pereira Gonzatto ${ }^{1}$, \\ Norton Borges Junior ${ }^{2}$, Roberto Lanna Filho ${ }^{1}$ \\ ${ }^{1}$ Departamento de Horticultura e Silvicultura, Universidade Federal do Rio Grande do Sul - UFRGS, \\ Porto Alegre/RS, Brasil \\ ${ }^{2}$ Celulose Riograndense - CMPC, Porto Alegre/RS, Brasil
}

\begin{abstract}
Powdery mildew is one of the main diseases in eucalyptus clonal nursery. The present work aimed to confirm the identity of the causal agent of powdery mildew in clonal seedlings of Eucalyptus spp., and to evaluate the susceptibility reaction of clones to this disease. Conidia were collected in minigardens for molecular identification of the pathogen. We assessed susceptibility by testing 4 clones: Clone 1 (Eucalyptus benthamii), Clone 2 (E. dunni), Clone 3 (E. benthamii) and Clone 4 (E. urophylla $\mathrm{x}$ E. globulus). Scale of classes was used for calculations of Disease Index (DI) and Final Incidence (I). Temporal analysis was performed using the Logistic and Gompertz models. The molecular identification confirmed the identity of the isolates approximate to Podosphaera pannosa (teleomorphic phase of Oidium eucalypti). The Gompertz model obtained a better adjustment to the severity and incidence data, and clones 1 and 2 showed greater susceptibility to eucalyptus powdery mildew.
\end{abstract}

Keywords: clonal nursery, Oidium eucalypti, incidence. 


\section{INTRODUCTION}

Powdery mildew diseases are caused by fungi that present powdery mycelium, and conidia that develop into chains on the surface of attacked tissues. In species of the genus Eucalyptus, it is considered a cosmopolitan disease reported in South Africa, Argentina, Brazil, Australia, Europe and the United States (Silva et al., 2001). It is also considered the main disease in nurseries, vegetation greenhouses and clonal mini-gardens of several species of the genus (Valeriano et al., 2015). Alfenas et al. (2009) reported that this pathogen has often been found on plants in nurseries, clonal mini-gardens with temporary flood hydroponics, or in drip irrigation tubes, where there is little or no leaf wetting.

The fungus spreads through wind, water splashes and by contact between infected and healthy plants (Furtado et al., 2000). Mucci et al. (1980) relate the disease to the etiological agent Oidium eucalypti Rostr. Krugner \& Auer (2005) have identified Sphaerotheca pannosa (synonym: Podosphaera pannosa) by cross-inoculation, confirming the identity as Oidium eucalypti.

The proper identification of the pathogen species is a key step to understand all pathogen-host cycle relations. The knowledge of such interactions is essential, not only to understand the disease itself, but mainly to create control strategies aiming to interfere with its cycle (Bergamin \& Amorim, 1996). The identification of phytopathogenic fungi is often based on morphological characteristics, but in many genera such characteristics are difficult to be observed in natural populations and are often affected by the environment (Faleiro et al., 2003).

According to Lima et al. (2008), the ideal classification should be based on the phylogeny of microorganisms. One of the most used regions for molecular identification of fungi is the so-called Internal Transcribed Spacer (ITS), because this region has more conserved phylogenetically sequences and, therefore, is more suitable for biodiversity studies (Reis et al., 2006). In addition, this is the most frequent region in most databases of fungal sequences.

Comparative epidemiology aims to identify similarities or differences between epidemics based on the nature or the behavior of the disease progression curve. The disease progress curve integrates the effects of the pathogen, the host and the environment into a single graph. The selection of an appropriate mathematical model to describe the disease progress curve is an important aspect of the temporal analysis, and such selection aims to estimate parameters used for a statistical analysis comparing curves (Madden et al., 2007). The interpretation of curve shapes and the determination of their components, such as the initial inoculum of the disease, progress rate, final index of the disease and area under the progress curve, are essential for the control of epidemics (Bergamin, 1995).

Within this context, knowledge of the epidemiology of Oidium eucalypti is key to establishing control measures at the right time, using adequate techniques to manage the disease. Thus, this study aims to confirm the identity of the causal agent of powdery mildew disease in clonal seedlings of Eucalyptus spp., and to evaluate the susceptibility of Eucalyptus spp. clones to the causal agent of the disease.

\section{MATERIAL AND METHODS}

This study was conducted at the Laboratory of Bacteriology of the Department of Phytosanitary of the Faculty of Agronomy of the Federal University of Rio Grande do Sul (UFRGS), Porto Alegre, RS, between 2015 and 2016. We used seedlings from four distinct genetic materials, two clones of Eucalyptus benthamii, one clone of E. dunnii and one clone of E. urophylla x E. globulus obtained by donation from the company Celulose Riograndense CMPC, located in the municipality of Guaíba, RS. The material was collected in the Horto Barba Negra $\left(30^{\circ} 20^{\prime} 41.8^{\prime \prime} \mathrm{S}, 51^{\circ} 14^{\prime} 42.2^{\prime \prime} \mathrm{W}\right)$, in the municipality of Barra do Ribeiro, RS.

Initially, the fungus was morphologically characterized through the evaluation of 200 conidia (Boesewinkel, 1980; Braun, 1987; Gorter, 1988) of Eucalyptus spp. with natural infection. The conidia collected in a same clone were considered as a single isolate. Microscopic slides of sporulated colonies were used to observe the shape, length and width of conidia in an Olympus optical microscope (400 X, MD50) containing an ocular with a micrometric ruler.

For the molecular identification of the causative agent of eucalyptus powdery mildew, the conidia of infected ministrains were sucked using a vacuum pump and transferred to Eppendorf microcentrifuge tubes 
containing $70 \%$ ethanol. The isolates were identified according to the collection performed on each clone, and sent to the Biological Institute of São Paulo for DNA extraction and sequencing. Pathogen DNA extraction was performed according to the CTAB method as described by Doyle \& Doyle (1991). Extracted genomic DNA samples were submitted to Polymerase Chain Reaction (PCR) for amplification of the rDNA ITS region with the primers ITS1 and ITS4 (White et al., 1990). The nucleotide sequences obtained were compared with those available on the GenBank for isolated pathogens. The sequences presenting the highest scores were selected and aligned, along with sequences obtained in the ClustalW algorithm sequencing. Phylogenetic analysis was conducted with 1,000 replicates by the software MEGA, version 6.0 (Tamura et al., 2013). The similarity of nucleotide sequences among isolates was calculated using the Basic Local Alignment Search Tool (BLAST) procedure from the National Center for Biotechnology Information (NCBI). A sequence of grapevine powdery mildew (Uncinula necator) was used as the "sister group" for the construction of the phylogenetic dendrogram.

To maintain the inoculum for the experiments, we collected leaves of the eucalyptus ministrains containing powdery mildew (source of inoculum) in the clonal minigarden of the company that supplied the material. Then, we performed the inoculation by scraping the conidia off the leaves surface using a brush with soft bristles, and transferring the conidia of the fungus to the adaxial surfaces of the upper third of the ministrains leaves. These inoculated ministrains were kept in a growth chamber at $25^{\circ} \mathrm{C}$ with a 12 -h photoperiod as a permanent source of inoculum for subsequent inoculations.

The susceptibility reaction test was performed with clone seedlings (obtained by minicutting) from four clones: clone 1 (Eucalyptus benthamii), clone 2 (E. dunni), clone 3 (E. benthamii) and clone 4 (E. urophylla $\times$ E. globulus) at about 90 days of age. Each treatment had 40 seedlings of each clone, divided into 4 replicates of 10 seedlings. The inoculation of seedlings was performed as described in the previous paragraph for the inoculation of ministrains. The inoculated seedlings were kept in a growth chamber at $25^{\circ} \mathrm{C}$ with a photoperiod of $12 \mathrm{~h}$ for 29 days. The irrigation of seedlings and ministrains was performed daily and manually using a graduated wash bottle, dampening only the substrate.
The experiment was completely randomized. In order to evaluate Incidence (I), the number of seedlings showing symptoms of Oidium eucalypti was counted weekly in each treatment.

We established a scale for severity assessment using a descriptive scale containing four classes: $0=$ absence of symptoms, $1=$ mild infection (presence of fungus mycelium in leaves without sporulation), $2=$ intermediate infection (sporulation on the first leaf pairs), and $3=$ high infection (leaf deformation, winding of the first pair of leaves and leaf fall). The scores of this descriptive scale were used to calculate the disease index (DI), in a range of $0-1$, expressed by Equation 1:

$\mathrm{DI}=\frac{\sum(\mathrm{Y} * \mathrm{Xy})}{\mathrm{Xt} * \mathrm{~h}}$

where: $\mathrm{Y}$ is the scale score; $\mathrm{X}_{\mathrm{y}}$ is the number of plants with a note $\mathrm{Y} ; \mathrm{X}_{\mathrm{t}}$ is the total number of plants; and $\mathrm{h}$ is the maximum value of the scale (McKinney, 1923).

For the temporal analysis of the behavior of the disease for each clone, the variables I and DI were submitted to a non-linear adjustment in relation to time for each clone. For this, the following recommended models for polycyclic diseases were used: Logistic and Gompertz. These models are composed of three parameters: $y_{0}$, the initial disease index; $y_{\max }$ the maximum (asymptotic) disease index; and $r$, the progress rate of the epidemic. The models were adjusted using the non-linear method and the PROC NLIN routine of the statistical package SAS $9.4^{\circ}$. The most appropriate model was chosen taking into account the highest value of the coefficient of determination $\left(R^{2}\right)$. The estimated parameters of the models were compared by $t$ test between clones in pairs taking into account their errors (Madden et al., 2007). A correlation analysis of the residues was also used to relate the DI to I data (Spolti et al., 2015).

In addition, I and DI data were analyzed by mixed models using the repeated measures method. The covariance structure that presented the best fit was selected according to Akaike and Bayesian information criteria (Silva et al., 2015). The means of the final evaluation, at 29 days, were compared by Tukey test at $5 \%$ probability.

\section{RESULTS AND DISCUSSION}

The causal agent of eucalyptus powdery mildew disease in the clones evaluated in this study was confirmed as Oidium eucalypti, by molecular identification (sequencing of 
the ITS region). The four sequenced isolates were molecularly identical, presenting a 516 bp fragment size. Therefore, we opted to present only one sequence. It aligned to sequences in the GenBank corresponding to the species Podosphaera pannosa (Figure 1). Silva \& Alfenas (1994) reported that eucalyptus powdery mildew is similar to that of roses, considering that the disease, for the second crop, has as its causal agent Sphaerotheca pannosa (Vallr. ex. Fr.) Lev.

The result of the identification are similar to the obtained by other authors, such as by Silva et al. (2003), who observed, during the nursery phase in the Minas Gerais region, powdery mildew in Eucalyptus citriodora and other species of the same genus caused by the fungus Sphaerotheca pannosa (synonym: Podosphaera pannosa), which is described as the sexual phase of O. eucalypti. In Brazil, in eucalyptus, only the anamorphic phase of the etiological agent has been found and identified as Oidium eucalypti Rostrup. (Ferreira, 1989). In 2014, in Korea, the first occurrence of powdery mildew caused by Podosphaera pannosa was identified in Corymbia citriodora (Cho et al., 2016).

The manifestation of powdery mildew in eucalyptus seedlings may be attributed to its high susceptibility to the disease, favorable environmental conditions and availability of inoculum (Silva et al., 2001). As shown in the phylogenetic dendrogram (Figure 1), we observe that there are previous records of Podosphaera pannosa occurring in other Eucalyptus and Rosa spp. species.

The symptoms and the structure of powdery mildew in clonal eucalyptus seedlings can be seen in Figure 2 . The shape of the conidia ranged from ellipsoid to ovoid (Figure 2B). The conidial chain formation was observed in the four isolates studied, and the mean values of the 200 conidia were $32.5 \times 20.7 \mu \mathrm{m}$ (length $\mathrm{x}$ width), with a maximum value of $40 \times 22.5 \mu \mathrm{m}$ and a minimum of $27.5 \times 17.5 \mu \mathrm{m}$.

In a study conducted by Silva et al. (2001), isolates from powdery mildew in Eucalyptus urophylla and Rosa sp. presented ellipsoid-ovoid conidia with mean sizes of $26.2 \times 14.2 \mu \mathrm{m}$ and $27.2 \times 14.2 \mu \mathrm{m}$, respectively. For Dhalia sp., the same authors found ovoid-cylindrical conidia with a mean size of $32 \times 16.8 \mu \mathrm{m}$. Our study shows similar results for the morphology of conidia of powdery mildew. We observed a similarity in length and width to the powdery mildew of Dhalia sp., and the same format as the powdery mildew of E. urophylla and Rosa sp. Mucci et al. (1980) found Oidium conidia

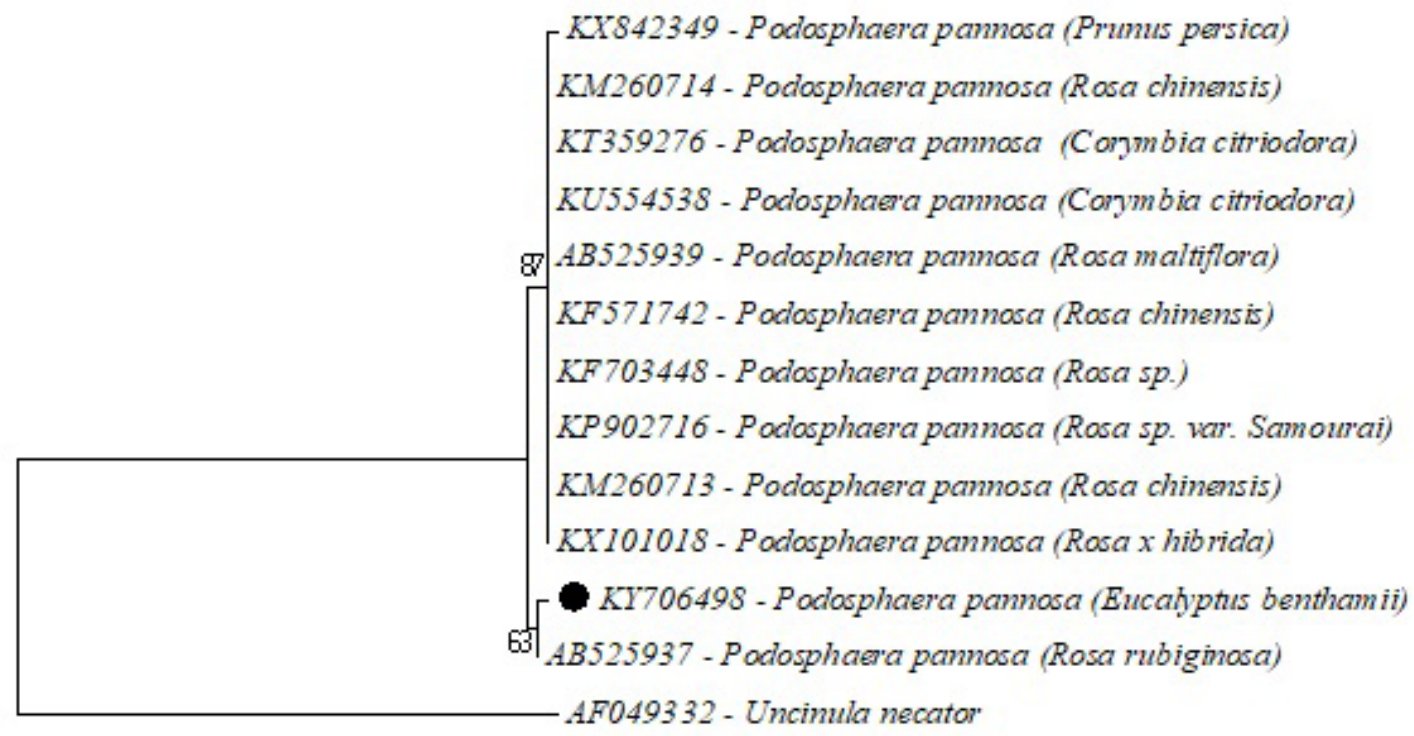

0.02

Figure 1. Phylogenetic dendrogram constructed for the isolate of powdery mildew from clonal seedlings of Eucalyptus spp. based on the Neighbor-joining statistical method, derived from the sequences of the ITSr DNA regions and aligned by the Tamura-Nei Model. 

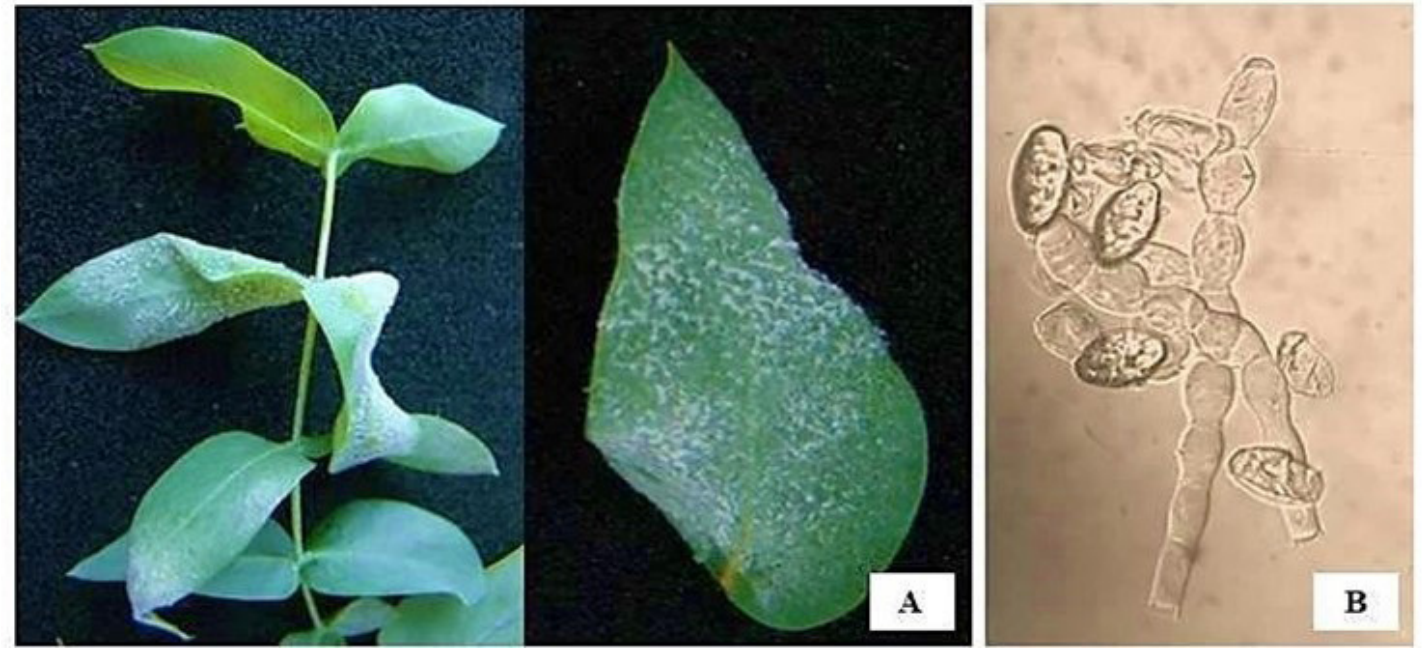

Figure 2. Symptoms of powdery mildew in clonal seedlings of Eucalyptus spp. and detail of the sporulation in the leaf (A); conidiophores and conidia of Oidium eucalypti (B).

originating from eucalyptus, with dimensions ranging between 21-35.75 $\times 13-20 \mu \mathrm{m}$. This demonstrates that the morphology of O. eucalypti conidia obtained in this study is similar both in shape and size to fungus conidia.

According to the susceptibility reaction test, all clones studied were susceptible. We observed symptoms caused by the pathogen. Among the mathematical models tested, the Gompertz model was the best fit for the progress curves for both incidence (I) and disease (DI) data for the four clones ( $\mathrm{R}^{2}$ between 0.78 and 0.97 ). The tested models explain the progress rate because the disease caused by Oidium eucalypti is polycyclic, in which the inoculum potential of the pathogen during the crop cycle is one of the main factors that determine the degree of incidence and the severity of the disease, being even more important at the beginning of plant development (Bergamin, 1995).

By the Gompertz model, the growth rate is accentuated at the onset of the disease, and rapidly changes to a slower growth (Madden et al., 2007). The clones studied showed a similar behavior. Chelal \& Hau (2015) used this same model to analyze the behavior of tomato plants infected with Oidium neolycopersici, obtaining high values (higher than 0.98 ).

Incidence (I) and disease index (DI) curves, produced by the Gompertz model, presented a different behavior for the four clones evaluated (Figure 3).

We observed that the DI of the clone 1 (E. benthamii) showed a higher rate of disease progression in the first
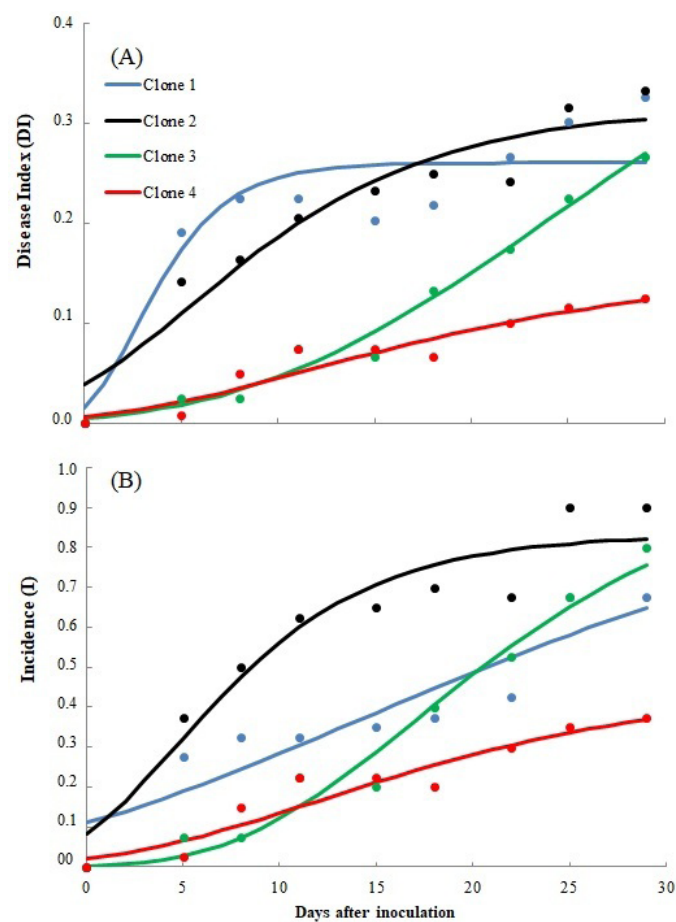

Figure 3. Temporal progression of disease index - DI (A) and incidence - I (B) of epidemics of powdery mildew (Oidium eucalypti) in four eucalyptus clones according to the Gompertz Model. Clone 1 (Eucalyptus benthamii); Clone 2 (E. dunni); Clone 3 (E. benthamii); Clone 4 (E. urophylla x E. globulus).

days after inoculation of powdery mildew (Figure 3A). With the passage of days, the disease tendency was towards a stabilization, which indicates that the pathogen could 
colonize the tissue easier at the beginning, proving to be more damaging to the infected plants of that clone. Subsequently, the DI values stabilized $(y \max =0.261)$, as shown in Table 1. Observing the curve of the clone 2 (E. dunnii), the disease also increased its intensity with the passage of time, standing out because it presented the highest disease index. The curves of the clones 3 (E. benthamii) and 4 (E. urophylla x E. globulus) initially presented low values of disease incidence and severity. However, from 12 days after inoculation, we observed that for the clone 3 , the DI tended to increase the severity of the disease, while for the clone 4 there was a tendency to stabilize the disease (Figure 3A).

In contrast, the I curves presented a different behavior when compared to DI curves. The incidence of the causal agent of powdery mildew in clone 2 (E. dunnii) was the highest compared to the other clones, in addition to reaching higher incidence rates in a shorter time. We also observed a propensity to increase the incidence of the disease by the behavior of the curves of the clones 1 and 3, both clones of E. benthamii.

In Figure 3, the clone 4 (E. urophylla $\mathrm{x}$ E. globulus) had the lowest DI and I of the disease. Thus, it was considered the clone least susceptible to powdery mildew disease compared to the others as evaluated in this study. Silva et al. (2014), in a study evaluating the partial resistance of eucalyptus rust (Puccinia psidii) in different species of Eucalyptus, observed that Eucalyptus urograndis (E. grandis x E. urophylla) presented a low average number of pustules per leaflet, low severity, long average latent period and low values of area below the disease progression curve, thus having a higher partial resistance to rust. This demonstrates that a eucalyptus hybrid may present a greater resistance and low incidence to fungal diseases.

The evaluation of incidence and severity of leaf spot caused by Cylindrocladium candelabrum on juvenile crops of E. benthamii showed a disease incidence in trees of 2.6-43.8\% and mean severity data between 1.2 and 2.9, evidencing a susceptibility of this species to the pathogen (Schultz et al., 2015).

The parameters $y_{0}, r$ and $y_{\max }$, estimated by the Gompertz model for O. eucalypti epidemics on the different clones evaluated, presented a significant difference only for incidence data (Table 1). The clone 1 had the highest initial disease index $\left(y_{0}=0.110\right)$, differing significantly from the clone $3\left(y_{0}=0.002\right)$. The progress rates of the epidemic were higher for the clones $2(r=0.177)$ and $3(r=0.106)$. By analyzing the parameter $y_{\max }$, we noted that the clones 1 and 3 showed $100 \%$ of incidence. Such values agree with the behavior of the curves represented by the model, in which the clones of E. benthamii and E. dunnii showed a high incidence of powdery mildew. The expression of symptoms of powdery mildew is directly related to the genetic differences of each eucalyptus clone. Grigoletti et al. (2005) reported E. benthamii as a species highly susceptible to Oidium sp. under nursery and greenhouse conditions. With respect to E. dunnii, we detected a high genetic variability of resistance to rust caused by Puccinia psidii, presenting a coefficient of genetic variation of 36.07 and $70 \%$ for evaluated progenies; they are thus rust-immune (Pinto et al., 2014).

Table 1. Parameters ${ }^{1}$ estimated by the Gompertz model for temporal analysis of the disease index and the incidence of Oidium eucalypti in seedlings of four Eucalyptus spp.

\begin{tabular}{|c|c|c|c|c|c|c|c|c|c|c|c|}
\hline \multirow{2}{*}{ Analysis } & \multirow{2}{*}{ Clone } & \multicolumn{10}{|c|}{ Parameters estimated by Gompertz model } \\
\hline & & $R^{2}$ & y0 & \pm error & & $r$ & \pm error & & $y_{\max }$ & \pm error & \\
\hline \multirow{4}{*}{$\begin{array}{l}\text { Disease Index } \\
\text { (DI) }\end{array}$} & $1^{2}$ & $0.85^{\star * * *}$ & 0.015 & 0.048 & \multirow{4}{*}{$\mathrm{ns}$} & 0.390 & 0.240 & \multirow{4}{*}{$\mathrm{ns}$} & 0.261 & 0.022 & \multirow{4}{*}{ ns } \\
\hline & 2 & $0.96^{* * * *}$ & 0.038 & 0.018 & & 0.138 & 0.038 & & 0.317 & 0.027 & \\
\hline & 3 & $0.92^{\star * * *}$ & 0.005 & 0.000 & & 0.062 & 0.034 & & 0.597 & 0.446 & \\
\hline & 4 & $0.78^{* * * *}$ & 0.007 & 0.010 & & 0.094 & 0.071 & & 0.151 & 0.070 & \\
\hline \multirow{4}{*}{ Incidence (I) } & 1 & $0.93^{* * * *}$ & 0.110 & 0.032 & $A^{*}$ & 0.056 & 0.077 & $\mathrm{~B}^{*}$ & 1.000 & 0.000 & $A^{*}$ \\
\hline & 2 & $0.97^{\star * * *}$ & 0.084 & 0.044 & $\mathrm{AB}$ & 0.177 & 0.038 & A & 0.832 & 0.044 & B \\
\hline & 3 & $0.92^{\star * * *}$ & 0.002 & 0.004 & B & 0.106 & 0.014 & A & 1.000 & 0.000 & A \\
\hline & 4 & $0.78^{\star * * *}$ & 0.021 & 0.021 & $\mathrm{AB}$ & 0.094 & 0.071 & $\mathrm{AB}$ & 0.452 & 0.210 & B \\
\hline
\end{tabular}

${ }^{1}$ Coefficient of variation $\left(\mathrm{R}^{2}\right)$, initial disease index $\left(y_{0}\right)$ and asymptotic $\left(y_{\max }\right)$, and epidemic rate of progress $(r)$ estimated by Gompertz model; ${ }^{2}$ Clone 1 (Eucalyptus benthamii); clone 2 (E. dunnii); clone 3 (E.benthamii); clone 4 (E.urophylla X E.globulus); ${ }^{* * * *} \mathrm{p}<0.0001 ;$

ns: Not significant; ${ }^{*}$ Means followed by the same letter do not differ from one another by the test $t$ at $5 \%$ probability. Being: clone 1

(Eucalyptus benthamii), clone 2 (E. dunni), clone 3 (E. benthamii) and clone 4 (E. urophylla x E. globulus). 
Sánchez Márquez et al. (2011), studying the occurrence of fungal species in juvenile and adult leaves of plantations of E. globulus, observed that, in general, juvenile leaves are more prone to infection by fungi, pathogens and endophytes than adult leaves. According to James \& Bell (2001), adult leaves of E. globulus and other species have thicker cuticles and a lower stomatal density than juvenile leaves. In comparative studies with juvenile leaves of susceptible and resistant genotypes of E. globulus, anatomical characteristics such as densities of palisade mesophylls, cuticle thickness and stoma wax cover were associated with resistance (Smith et al., 2007). Such characteristics may explain the low susceptibility to severe and incidence of powdery mildew by the hybrid clone (E.urophylla x E. globulus).

By observing the proportion of the disease for both the $\mathrm{DI}_{\mathrm{f}}$ and the $\mathrm{I}_{\mathrm{f}}$ values, we found that the clone 4 (hybrid) showed a significant difference from the other clones, with a $\mathrm{DI}_{\mathrm{f}}$ and an $\mathrm{I}_{\mathrm{f}}$ ratio of 0.1250 and 0.3750 , respectively. Thus, this clone stands out as the least susceptible to the disease. On the other hand, the clones 1 and 3 of E. benthamii and the clone 2 of E. dunnii were the most susceptible, presenting high proportions and exceeding the value of 0.6000 when assessed for final incidence of the disease (Table 2).

The correlation between DI and I data throughout the experiment showed that the clone 1 reached, over the evaluations, higher ratios of IDI (greater than 0.4) and a maximum incidence ratio of 0.8 . This clone developed higher and lower DIs during the first half of the evaluated period, which justifies the greater slope of the line (Figure 4). In contrast, clone 2 presented low DI values. However, it presented high I values throughout the evaluations, reaching the ratio 1 . Clone 3 also had high I values, reaching a ratio greater than 0.8 . Clone 4 presented values lower than 0.3 for DI and lower than 0.8 for I (Figure 4). This comparison between disease proportions among clones once again reinforces the susceptibility of the clones 1 and 2 to the disease.

Mafia et al. (2012) analyzed the Pearson correlation coefficients obtained between eucalyptus rust severity values (Puccinia psidii), evaluated ex vitro at 20 days, and values of incidence of disease with the pathogen inoculated in explants in vitro. The values were $0.93,0.98$ and $0.98 \%$ at 7,11 and 14 days after inoculation, respectively. The authors observed a
Table 2. Final disease index (DI) and final incidence ( $\left.\mathrm{I}_{f}\right)$ obtained at the 29 days of evaluations of the disease caused by Oidium eucalypti in the different eucalyptus clones.

\begin{tabular}{|clc|}
\hline Clone & \multicolumn{1}{c}{ DI $_{f}$} & $\mathbf{I}_{f}$ \\
\hline Eucalyptus benthamii (clone 1) & $0.3267 \mathrm{~A}^{*}$ & $0.6750 \mathrm{~A}$ \\
\hline Eucalyptus dunnii (clone 2) & $0.3333 \mathrm{~A}$ & $0.9000 \mathrm{~A}$ \\
\hline Eucalyptus benthamii (clone 3) & $0.2667 \mathrm{AB}$ & $0.8000 \mathrm{~A}$ \\
\hline E.urophylla x E.globulus (clone 4) & $0.1250 \mathrm{~B}$ & $0.3750 \mathrm{~B}$ \\
\hline Variation causes & \multicolumn{1}{c}{ Probability (F test) } \\
\hline Clone & 0.0018 & $<0.0001$ \\
\hline Period & $<0.0001$ & $<0.0001$ \\
\hline Clone $\times$ Period & 0.0529 & 0.0454 \\
\hline
\end{tabular}

* Means followed by the same letter do not differ from one another by the test Tukey at $5 \%$ probability.

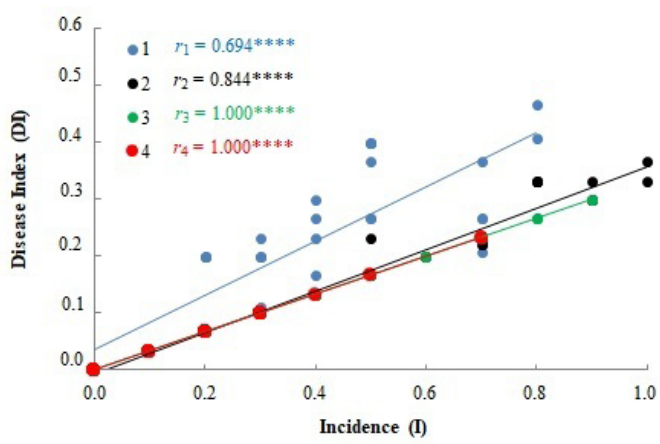

Figure 4. Correlation of residues between disease index (DI) and incidence (I) of Oidium eucalypti in four eucalyptus clones. Clone 1 (Eucalyptus benthamii); Clone 2 (E. dunnii); Clone 3 (E.benthamii); Clone 4 (E. urophylla X E. globulus); p <0.0001; R, Pearson correlation coefficients. Porto Alegre, RS, 2015.

different behavior among eucalyptus clones and reported that the most resistant clones had the same behavior between evaluation intervals.

Valeriano et al. (2015) obtained a significant difference in five different clones of E. urograndis from the first evaluation of incidence of powdery mildew at 7 days, with a lower incidence of the pathogen in two clones, and at the last evaluation 35 days after the onset of the disease.

With the data obtained in this study, we verified that the use of resistant clones might avoid the incidence of diseases, contributing to the success in the management of diseases in seedlings of this forest species. 


\section{CONCLUSIONS}

Oidium eucalypti is the causal agent of powdery mildew disease in clonal seedlings of Eucalyptus, as confirmed by molecular analysis.

Clone 1 (Eucalyptus benthamii), clone 2 (E. dunnii) and clone 3 (E. benthamii) are considered more susceptible to powdery mildew, and clone 4 (E. urophylla $\mathrm{x}$ E. globulus) is the least susceptible. The latter had the lowest disease index at the end of the evaluation.

\section{ACKNOWLEDGEMENTS}

We thank Coordenação de Aperfeiçoamento de Pessoal de Nível Superior - CAPES, for the granting of a master's degree grant from the first author and the Company CMPC - Celulose Riograndense, for the donation of the seedlings of Eucalyptus spp. and for helping to carry out this research.

\section{SUBMISSION STATUS}

Received: 19 july, 2017

Accepted: 20 aug., 2017

\section{CORRESPONDENCE TO}

\section{Marciéli Pitorini Bovolini}

Departamento de Horticultura e Silvicultura, Universidade Federal do Rio Grande do Sul - UFRGS, Av. Bento Gonçalves, 7712, CEP 91540-000, Porto Alegre, RS, Brasil e-mail: m.bovolini@hotmail.com

\section{REFERENCES}

Alfenas AC, Zauza EAV, Mafia RG, Assis TF. Clonagem e doenças do eucalipto. 2. ed. Viçosa: UFV; 2009.

Bergamin A Fo. Curvas de progresso da doença. In: Bergamim A Fo, Kimati H, Amorin L, editors. Manual de fitopatologia. São Paulo: Ceres; 1995.

Bergamin A Fo, Amorim L. Doenças de plantas tropicais: epidemiologia e controle econômico. São Paulo: Ceres; 1996.

Boesewinkel HJ. The morfology of the imperfect states of powdery mildews (Erysiphaceae). Botanical Review 1980; 46(2): 167-224. http://dx.doi.org/10.1007/BF02860869.

Braun U. A monograph of the Erysiphales (powdery mildews). Berlin: J. Cramer; 1987.
Chelal J, Hau B. Temporal dynamics of powdery mildew (Oidium neolycopersici) and its effects on the host growth dynamics of tomato. Journal of Phytopathology 2015; 163(9): 711-722. http://dx.doi.org/10.1111/jph.12368.

Cho SE, Park JH, Lee SH, Lee CK, Shin HD. Occurrence of powdery mildew caused by Podosphaera pannosa on lemon eucalyptus. Forest Pathology 2016; 46(3): 264-266. http://dx.doi.org/10.1111/efp.12277.

Doyle JJ, Doyle JL. Isolation of plant DNA from fresh tissue. Focus 1991; 1: 13-15.

Faleiro FG, Luz EDMN, Cerqueira AO, Rocha CSS. Uso de marcadores RAPD na classificação de isolados de Phytophthora spp. causadores da podridão parda do cacaueiro no Brasil. Fitopatologia Brasileira 2003; 28(3): 312-315. http://dx.doi.org/10.1590/S0100-41582003000300015.

Ferreira FA. Patologia florestal: principais doenças florestais no Brasil. Viçosa: SIF; 1989.

Furtado EL, Santos CAG, Takahashi SS, Camargo FRA. Doenças em viveiros de Eucalyptus sp: diagnóstico e manejo. Botucatu: Votorantim/Celulose e Papel; 2000.

Gorter GJMA. Identification of South African Erysiphaceae with a key to the species. Phytophylactica 1988;20: 113-119.

Grigoletti A Jr, Bizi RM, Auer CG. Oidium sp. em mudas de eucalipto. Colombo: Embrapa Florestas; 2005. (Comunicado Técnico; no. 144).

James AS, Bell DT. Leaf morphological and anatomical characteristics of heteroblastic Eucalyptus globulus ssp. globulus (Myrtaceae). Australian Journal of Botany 2001; 49(2): 259-269. http://dx.doi.org/10.1071/BT99044.

Krugner TL, Auer CG. Doenças dos eucaliptos. In: Kimati H, Amorim L, Bergamin Fo A, Camargo LEA, Rezende JAM, editors. Manual de fitopatologia: doenças das plantas cultivadas. São Paulo: Agronômica CERES; 2005.

Lima AA, Queiroz PR, Santos CF, Tutunji VL, Mello SCM, Lima LHC. Identificação molecular de linhagens de fungos pertencentes aos gêneros Aspergillus, Penicillium e Fusarium utilizando marcadores RAPD. Brasília: Embrapa Recursos Genéticos e Biotecnologia; 2008.

Madden LV, Hughes G, Van Den Bosch F. The study of plant disease epidemics. St. Paul: American Phytopathological Society; 2007.

Mafia RG, Marchesi HP, Aun CP. Avaliação de clones de eucalipto para resistência à ferrugem em condições de micropropagação. Revista Árvore 2012; 36(5): 843-850. http://dx.doi.org/10.1590/S0100-67622012000500006.

McKinney $\mathrm{HH}$. Influence of soil, temperature and moisture on infection of wheat seedlings by Helminthosporium sativum. Journal of Agricultural Research 1923; 26: 195-217.

Mucci ESF, Pitta GPS, Yokomizo NKS. Oídio em mudas de eucalipto. São Paulo: Instituto Florestal/Instituto Biológico; 1980. 
Pinto CS, Costa RML, Moraes CB, Pieri C, Tambarussi EV, Furtado EL et al. Genetic variability in progenies of Eucalyptus dunnii Maiden for resistance to Puccinia psidii. Crop Breeding and Applied Biotechnology 2014; 14(3): 187193. http://dx.doi.org/10.1590/1984-70332014v14n3a28.

Reis FB Jr, Reis VM, Teixeira KRS. Restrição do 16S-23S DNAr intergênico para avaliação da diversidade de Azospirillum amazonense isolado de Brachiaria spp. Pesquisa Agropecuária Brasileira 2006; 41(3): 431-438. http://dx.doi.org/10.1590/S0100-204X2006000300009.

Sánchez Márquez S, Bills GF, Zabalgogeazcoa I. Fungal species diversity in juvenile and adult leaves of Eucalyptus globulus from plantations affected by Mycosphaerella leaf disease. Annals of Applied Biology 2011; 158(2): 177-187. http://dx.doi.org/10.1111/j.1744-7348.2010.00449.x.

Schultz B, Sbravatti JA Jr, Auer CG, Santos AF. Impacto damancha foliar causada por Cylindrocladium candelabrumem plantios jovens de Eucalyptus benthamiiem Rio Negrinho - SC. Ciência Florestal 2015; 25(2): 307-316. http://dx.doi. org/10.5902/1980509818448.

Silva DEM, Azevedo LAS, Poltronieri TPS. Avaliação da resistência de espécies de eucalipto à ferrugem (Puccinia psidii Winter). Summa Phytopathologica 2014; 40(1): 5462. http://dx.doi.org/10.1590/S0100-54052014000100008.

Silva EM, Duarte JB, Reis AJS. Seleção da matriz de variância-covariância residual na análise de ensaios varietais com medidas repetidas em cana-de-açúcar. Ciência Rural 2015; 45(6): 993-999. http://dx.doi.org/10.1590/0103$8478 \mathrm{cr} 20141531$

Silva MDD, Alfenas AC, Maffia LA, Zauza EAV. Etiologia do oídio do eucalipto. Fitopatologia Brasileira 2001; 26(2): 201205. http://dx.doi.org/10.1590/S0100-41582001000200015.

Silva MDD, Alfenas AC, Maffia LA, Zauza EAV. Germinação de conídios de Sphaerotheca pannosa obtidos de eucalipto.
Fitopatologia Brasileira 2003; 28(6): 674-677. http://dx.doi. org/10.1590/S0100-41582003000600014.

Silva MDD, Alfenas AC. Identificação de Oidium originário do eucalipto, feijoeiro e urucunzeiro, e influência de fatores do ambiente na germinação de conídios de Sphaerothecapannosa. Fitopatologia Brasileira 1994; 19: 154.

Smith AH, Gill WM, Pinkard EA, Mohammed CL. Anatomical and histochemical defence responses induced in juvenile leaves of Eucalyptus globulus and Eucalyptus nitens by Mycosphaerella infection. Forest Pathology 2007; 37(6): 361-373. http://dx.doi.org/10.1111/j.14390329.2007.00502.x.

Spolti P, Shah DA, Fernandes JMC, Bergstrom GC, Del Ponte EM. Disease Risk, spatial patterns and incidenceseverity relationships of Fusarium head blight in no-till spring wheat following maize or soybean. Plant Disease 2015; 99(10): 1360-1366. http://dx.doi.org/10.1094/ PDIS-09-14-0944-RE.

Tamura K, Stecher G, Peterson D, Filipski A, Kumar S. MEGA6: Molecular Evolutionary Genetics Analysis version 6.0. Molecular Biology and Evolution 2013; 30(12): 2725-2729. http://dx.doi.org/10.1093/molbev/mst197. PMid:24132122.

Valeriano R, Pozza EA, Santos LA, Chaves E, Barbosa MP Jr, Ferreira MA. Escala diagramática e reação diferencial de clones para Oídio do Eucalipto. Scientia Forestales, Piracicaba 2015; 43(105): 51-61.

White TJ, Bruns TD, Lee S, Taylor J. Amplification and direct sequencing of fungal ribosomal RNA genes for phylogenetics. In: Innis MA, Sninsky JJ, Gelfand DH, White TJ. PCR Protocols: a guide to methods and applications. London: Academic Press; 1990. http://dx.doi.org/10.1016/ B978-0-12-372180-8.50042-1. 